UDC 811.111'24:629.12

DOI https://doi.org/10.24919/2308-4863/42-3-24

Iryna SEMENIUK ZUMRUTDAL, orcid.org/0000-0003-1987-8262

Candidate of Philological Sciences, Professor at the Department of Maritime Business Management Piri Reis University (Istanbul,Turkey)isemeniuk@pirireis.edu.tr

\title{
CHALLENGES IN ENGLISH ACADEMIC WRITING: ON-LINE COURSE
}

English is now the overwhelmingly dominant language in academia since academic communities use English as the default language, and there is a consequent development towards an increase in English medium teaching in Turkey in general. Turkish universities today are becoming increasingly bilingual. The number of programs offered in English has tripled in the last five years in Turkey. Turkey has chosen to participate in the Bologna process, which has led to increased academic mobility and a number of student exchange programs. With visiting scholars and exchange students, Turkish universities are becoming increasingly diverse linguistically (Björkman, 2008). This is no exception to Piri Reis University, a leading maritime university and a major provider of Turkey's maritime research and education. English is the language of instruction in the later years of many programs at Piri Reis University, and it is the only language of instruction in Master's programs and higher levels. In view of the recent changes due to COVID 19 pandemic Pire Reis University has initiated a large scale on-line studies project into all programms including the area of teaching academic writing for professional purposes to future maritime engineers. The purpose of this paper is to discuss some issues associated with the new trends of teaching English when it comes to professional engineers' education in a maritime university. The paper also reveals the problem of teaching academic writing on-line for professional purposes to future maritime engineers in Turkey. A theoretical analysis of the problem is given. The article also presents a preliminary investigation on the challenges in English academic writing in on-line context faced by engineering students at the Faculty of Engineering, Piri Reis University, Turkey.

Key words: academic writing challenges, on-line education, professional education, maritime engineers.

Ірина СЕМЕНЮК ЗУМРУТДАЛ, orcid.org/0000-0003-1987-8262 кандидат філологічних наук, професор кафедри управління морським бізнесом Університету Пірі Рейса (Стамбул, Туреччина) isemeniuk@pirireis.edu.tr

\section{ВИКЛИКИ ЩОДО НАВЧАННЯ АНГЛОМОВНОГО АКАДЕМІЧНОГО ПИСЬМА: ОНЛАЙН-КУРС}

У наш час англійська мова є домінантною в академічних колах, оскільки академічні спільноти використовують англійську як стандартну, з огляду на щзо в Туреччині спостерігається тенденція до розширення викладання англійською мовою. Сьогодні у більшості турецььких університетах навчання проводиться двома мовами. За останні п'ять років кількість програм англійською мовою, пропонованих у Туреччині, зросла втричі. Туреччина прийняла рішення долучитися до Болонського процесу, в результаті чого підвищилась академічна мобільність i кількість програм обміну студентами. Турецькі університети, які відвідують вчені та студенти з обміну, стають усе більш лінгвістично різноманітними (Björkman, 2008). Це не виняток для Університету Пірі Рейса як провідного морського університету і провайдера досліджень у сфері морської науки й освіти в Туреччині. В останні роки навчання за багатьма програмами в Університеті Пірі Рейса проводиться англійською мовою, і ие єдина мова навчання у програмах магістратури та вищих ступенів. 3 огляду на останні зміни, пов'язані з пандемією COVID-19, Університет Пірі Рейса ініціював великомасштабний проєкт онлайн-досліджень за всіма програмами, включаючи сферу навчання академічного письма майбутніх суднових механіків. Мета статті - розглянути деякі питання, пов 'язані з новими тенденціями у викладанні англійської мови, а саме навчання суднових механіків у морському університеті. Розкрито проблему навчання академічного письма в онлайн-режимі майбутніх суднових механіків у Туреччині. Представлено попереднє дослідження проблем, з якими зіштовхуються курсанти-механіки Університету Пірі Рейса під час онлайн-навчання академічного письма англійською мовою.

Ключові слова: виклики щуодо навчання академічного письма, онлайн-навчання, професійна освіта, суднові механіки. 
Problem statement. English has become more important to learn than ever before with the breakdown of the COVID 19 pandemic in the world. And English teaching on-line is one of the necessary growing areas in outstanding engineers' training education especially under current COVID 19 realities. In view of the recent changes due to COVID 19 pandemic Pire Reis University has initiated a large scale on-line studies project into all programms including the area of teaching academic writing for professional purposes to future maritime engineers.

Our presupposition has been that this research subject in the area of language teaching methodology for professional purposes would bring us closer to understanding the driving forces, vehicles and destinations that lie behind successful on-line curricular and guide future specialists towards the study of English as a foreign language for professional purposes during COVID-19 pandemic.

Purpose of the research. From a very general perspective, future maritime engineers at Piri Reis University learn English for academic degree (English for academic purposes), implementing a successful career in the chosen professional field (English for occupational purposes), addressing individual tasks in profession (English for individual purposes). With this picture in mind, the essence of teaching academic writing on-line for professional purposes under COVID-19 reality means that the Faculty of Engineering is to meet the aspirations of our students to continue their education in a different cultural environment or to seek employment there. We have to consider the natural desire of our students to achieve the mastery of a profession, for the sake of promotion in one's position. But at the same time teaching academic writing on-line requires our awareness of on-line classroom environment problems and obstacles that may influence the existence of students personally significant goals in the chosen occupational area.

Recent research and publications. The challenges and problems in English academic writing faced by engineering students in Turkish universities are due to their linguistic and literacy settings, their stance on academic writing and universities giving privilege to middle-class literacy practices. As an example, students at the maritime universities are presumed to have excellent English language and high level of thinking skills e.g. logical and critical thinking as well as analytical and innovative skills. Nevertheless, in recommending for these high level thinking skills, universities are usually not aware or not concerned about the schooling experiences of students and how they have an impact on their writ- ings in the university (Pineteh, 2012). So, students who have the privilege of attending various English language proficiency courses to sharpen their language skills will have an advantage compared to those who do not have such experience. Hence there is a wide gap between the haves and the have nots. To express this more articulately academic writing is a literacy practice rather than a skill as writing in higher education is not merely a set of methods that are separate from the social context (Archer, 2010).

For non-native speakers English academic writing is a challenging task who are in the transition period from secondary education to tertiary or university education (Fong, 2009). The engineering students face double challenge as they not have to cope with understanding new subjects at the university but also the ability to understand English which is used as the medium of instruction. Although many of future maritime engineers have learned English for 1 year at the English Preparatory Department, they still faced enormous challenge in understanding English which is used at university level. They have to understand the core subjects although most of the references are not in their native language and there are many new technical jargons and terminologies that they have to understand. They also have to acquire the writing skills especially in their discipline and be good in using the relevant references (Wong Sowat, 2013). With the breakdown of the COVID-19 pandemic in the world the discussion on the problem of English language proficiency among future maritime engineers and new trends of teaching Academic English on-line in Turkey including Piri Reis University has become very actual.

The main text. Learning English academic writing on-line for professional purposes brings changes into the pedagogical ideology of the teaching process. This regards primarily and importantly the attention now given to the on-line course output. An important transition is now being observed in the linguistic contents of the on-line curricular. The content of on-line learning is no longer purely linguistic, but rather a mix of digital, communicative and professional competence. The context of on-line learning is not made of everyday life simulations, but rather vocational situations that would preferably reflect not so much the scope of the English language lexis and grammar but rather the richness and innovative leadership in the chosen professional areas (Millrood, 2014).

The on-line curricular of teaching English academic writing for professional purposes can no longer be as stable and everlasting as the lexis-and-grammar based curricular in the not so very 
remote past. The reason is that cutting age information relevant to a certain profession is changing much more rapidly than the English grammar or vocabulary stock. This has to be reflected in the on-line curricular undergoing permanent change as synchronized with the change in the state of the art in a certain profession. On-line course output is measured against the standards that are dictated not only by language teaching priorities, but rather by a set of competences required by the State Educational Standard in a chosen professional field as approved by the Ministry of Education of Turkey. The change in pedagogical ideology leads to the change in the on-line teaching methodology.

Research data collection. The present research was based on a questionnaire in the form of statements relating to on-line the challenges in English academic writing studies involving 120 engineering freshmen from the Faculty of Engineering. Their majors include electrical engineering, mechanical engineering and civil engineering, which are the mainstream of the engineering discipline in the context of Turkish tertiary maritime education. The freshmen were asked to express the degree of their agreement with the statements in the questionnaire using the following scale: +3 strongly agree, +2 agree, +1 partially agree, 0 no idea, -1 partially disagree, -2 disagree, -3 strongly disagree. The UBIT LMS SaaS software package was used for processing the statistical the data from the valid responses.

Engineering Students' Academic Writing Challenges in On-line Context: Results: The descriptive statistics of the questionnaire responses are given in Table 1:

Discussion. From Table 1, it can be seen that the highest scoring is registered in responses to the statements "I need a long time to ponder what to write on-line" $(0,571429)$ and "I feel I have a difficulty in organizing my academic writing" $(0,048619)$. The deviation is a little lower but equally significant in the graduates' assessments of statements "When I write a composition on-line I feel I have nothing to say about the topic" $(0,47519)$, "I I feel I have a problem with mechanics" $(0,38095)$, "I do not know how to plan the structure" $(0,39095)$ and others. This means that engineering students have some problems in the structure planning of the text (including how to start and end the passage), cohesion of sentences and paragraphs, presentation of thesis statements and topic sentences, but such difficulties are not too severe and their occurrence is not frequent.

Next academic writing difficulty in on-line context that engineering students have in the pres- entation of content lies in lack of academic vocabulary $(0,428571)$ and the appropriate use of academic vocabulary $(0,095238)$, finding synonyms $(0,142857)$ and pertinent words $(0,285714)$ to express their ideas. Moreover, due to lexical difficulties, sometimes they need to turn to literal translation in English writing (0,275214). Apart of lexical difficulties, engineering students have often fail to find proper words or phrases and have to consult a dictionary $(-0,14286)$.

In addition, the learners also think that they have great difficulty in producing new and original ideas when undertaking academic writing tasks on-line $(-0,14286)$. Moreover, engineering students need to spend too much time in planning content and forming ideas $(0,571429)$, and it is also hard for the learners to take notes during the on-line class $(0,142857)$, find enough materials for writing on-line $(0,47619)$ in writing, and prepare presentations on-line $(0,238095)$. Additionally, their writing is sometimes empty in content and is devoid of substance $(-0,14286)$.

The statistics of the questionnaire shows that all engineering students of Piri Reis University face difficulties during on-line classes in academic writing. The deviations in scoring to the statements shows the students differ among themselves along the lines of their English language competence, the use of academic writing and ability to get involved in on-line language studies.

Conclusions. The present study conducted a survey on Piri Reis University maritime engineering students' self-perceived difficulties in English academic writing, and its findings indicate that the students, as English as a foreign language learners, when undertaking writing tasks on-line, are likely to experience barriers in several aspects including content, structure and language. Their greatest difficulties in English academic writing lie in the use of English language and in the process of English writing. The presentation of content also poses a big challenge for maritime engineering students, while they consider their problem in structure to be less severe. The level of on-line academic writing competence in English demonstrated by future maritime engineers of Piri Reis University is apparently modest.

In addition, Piri Reis University engineering students' challenges in generating informative, profound and creative ideas on-line can partly be ascribed to the overemphasis of practical skills and necessity of bringing changes into the pedagogical ideology and the methodology of the on-line teaching process due to COVID 19 realities. 


\begin{tabular}{lcccc}
\hline \multicolumn{1}{c}{ Statements } & Min & Max & Mean & Std. Deviation \\
\hline I feel I have a problem while preparing presentations on-line. & -1 & 1 & 0,238095 & 0,83094897 \\
\hline I feel I have a difficulty in organizing my article. & -1 & 1 & 0,048619 & 0,920662287 \\
\hline I feel I have a problem with grammatical accuracy in writing on-line. & -1 & 1 & 0,047619 & 0,920662287 \\
\hline I face a problem with the appropriate use of academic vocabulary in writing on-line. & -1 & 1 & 0,095238 & 0,94365046 \\
\hline I feel I have a problem with mechanics (spelling, punctuation, format, etc.) & -1 & 1 & 0,38095 & 0,864649668 \\
\hline I feel I have a problem with taking notes during the on-line class. & -1 & 1 & 0,142857 & 0,91025899 \\
\hline I cannot find enough materials for writing on-line. & -1 & 1 & 0,47619 & 0,813575296 \\
\hline I lack new and original ideas, and it is difficult for me to convey something new. & -1 & 1 & $-0,14286$ & 0,72702918 \\
\hline I cannot find pertinent examples to illustrate my point. & -1 & 1 & $-0,42857$ & 0,746420027 \\
\hline I need a long time to ponder what to write on-line. & -1 & 1 & 0,571429 & 0,676123404 \\
\hline I feel my composition is devoid of substance. & -1 & 1 & $-0,14286$ & 0,853563957 \\
\hline When I write a composition on-line I feel I have nothing to say about the topic. & -1 & 1 & 0,47519 & 0,74960307 \\
\hline I feel my vocabulary is not large enough to fully express what I want to convey. & -1 & 1 & 0,428571 & 0,870139562 \\
\hline I have to literally translate the Turkish meaning I want to express into English, just because & -1 & 1 & 0,275214 & 0,707106781 \\
\hline I cannot find pertinent words in English. & -1 & -1 & 0,285714 & 0,717137166 \\
\hline I have to abandon some ideas that I want to express, just because I cannot find pertinent \\
words.
\end{tabular}

\section{BIBLIOGRAPHY}

1. Archer, A. Challenges and potentials for writing centres in South African tertiary institutions. South African Journal of Higher Education, 24 (4), 2010. pp. 495-150.

2. Björkman, B. English as the Lingua Franca of Engineering: The Morphosyntax of Academic Speech Events. Nordic Journal of English Studies, 7 (3), 2008. pp. 103-122.

3. Evans V., et al. Career Paths. Express Publishing. 2011. 50 p.

4. Fong, L. L., Alam, S., Kim, M. L. S., Stapa, S. H., \& Darus, S. The Culture of Writing of L2 Writers in Transition from Secondary School to Postsecondary Education. Asian Journal of UniversityEducation, 5 (2), 2009. Pp. 45-65.

5. Millrood R. Teaching English to Engineers at a Tertiary Level in Russia. Procedia - Social and Behavioral Sciences 154, 2014. pp. 199-203.

6. Pineteh, E. Using virtual interactions to enhance the teaching of communication skills to information technology students. British Journal of Educational Technology, 43 (1), 2012. pp. 85-96.

7. Wong Sowat N.S. Creating success in academic writing from secondary to higher education: a workshop for nonnative speakers of English. Master Thesis, Queen's University Kingston, Ontario, Canada. 2013. 228 p.

\section{REFERENCES}

1. Archer, A. Challenges and potentials for writing centres in South African tertiary institutions. South African Journal of Higher Education, 24 (4), 2010. pp. 495-150.

2. Björkman, B. English as the Lingua Franca of Engineering: The Morphosyntax of Academic Speech Events. Nordic Journal of English Studies, 7 (3), 2008. pp. 103-122.

3. Evans V., et al. Career Paths. Express Publishing. 2011. 50 p.

4. Fong, L. L., Alam, S., Kim, M. L. S., Stapa, S. H., \& Darus, S. The Culture of Writing of L2 Writers in Transition from Secondary School to Postsecondary Education. Asian Journal of UniversityEducation, 5 (2), 2009. Pp. 45-65.

5. Millrood R. Teaching English to Engineers at a Tertiary Level in Russia. Procedia - Social and Behavioral Sciences 154, 2014. pp. 199-203.

6. Pineteh, E. Using virtual interactions to enhance the teaching of communication skills to information technology students. British Journal of Educational Technology, 43 (1), 2012. pp. 85-96.

7. Wong Sowat N.S. Creating success in academic writing from secondary to higher education: a workshop for nonnative speakers of English. Master Thesis, Queen's University Kingston, Ontario, Canada. 2013. 228 p. 